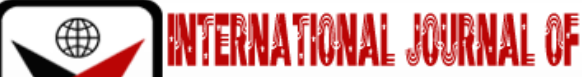

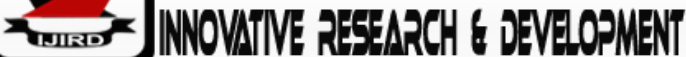

ISSN 2278-0211 (Online)

\section{The Reality of Property Registration for Land Ground in Preventive Perspective Incidence Dispute Arrange the Effort State}

\author{
Dr. Johamran Pransisto \\ Lecturer, Department of Law, Amsir Law College Parepare, Indoensia
}

\begin{abstract}
:
This study aims to know and analyze the nature of the registration of property rights on land from the perspective of prevention of the occurrence of state administrative disputes. This research uses empirical research methods. The results showed that the nature of the registration of property rights on land in the perspective of prevention of the occurrence of state administrative disputes is to realize legal certainty through the management of physical data and proof of rights in the registration of property rights on land and implement concrete certainty of administration and presentation of information, especially the registration of property rights on land has not been running effectively.
\end{abstract}

Keywords: Nature of land registration, property rights, prevention, and disputes

\section{Introduction}

Land is an important economic factor and has strategic value seen in any aspect either socially, politically or culturally. Population and economic growth have spawned a variety of excesses in terms of ownership of land rights and obligations, whether it be social or individual. In this case, the government seeks to overcome various problems arising by organizing this most strategic problem by affirming the legal certainty of land rights and obligations through Law No. 5 of 1960 on Agrarian Fundamentals Regulations.

To obtain a guarantee of legal certainty and certainty of land rights, the community needs to register their land to obtain a certificate of land rights that serves as powerful proof of land ownership. Recognizing the demands of service to the community requires the National Land Agency of the Republic of Indonesia to conduct land registration including property rights based on legislation. Legal certainty that is the purpose of land registration in Indonesia is essential to include the certainty of objects, certainty of rights, and certainty of subjects.

Things that are obstacles in the implementation of land registration in addition to the substance of the law, legal structure, legal culture, public legal awareness, facilities and infrastructure, coordination, also the objective state of the land itself which in addition to large numbers and spread in a large area most of its control is not supported by evidentiary tools that are easy to obtain and trustworthy truth. In addition, the legal provisions for the basis of its implementation are not felt to provide enough possibilities for the implementation of land registration in a short time with more satisfactory results.

Therefore, to increase better support for national development by providing legal certainty in the field of land, it is considered necessary to make improvements to the provisions governing land registration.

Lately, there have been symptoms that land problems are not only caused by juridical matters, but develop into multisectors (agriculture, industry, government, transmigration, etc.) that use the land, or become multi-dimensional state issues (cultural, political, economic, social, and defense and security) so that when it will be solved by the approach taken by the government as it is now is not enough solely technical juridical, but also concerns socioeconomic considerations. (Lutfi I Nasution, 2002: 216)

Based on the background above, it is formulated what is the nature of the registration of property rights on land in the perspective of preventing the occurrence of state administrative disputes, how to handle state administrative disputes on the certificate of property rights on land that is the object of the State Administration dispute in the Makassar State Administrative Court, and what factors affect the registration of property rights to the land from the perspective of prevention of the onset of state administration.

The provision of legal certainty guarantees in the field of land requires the availability of written legal devices, which are complete and clear and implemented consistently and the implementation of effective land registration.

With the availability of written legal devices anyone interested will easily know what information is available for him to control and use the land he needs, how to obtain it, the rights of obligations and prohibitions that exist in controlling the land with certain rights, what sanctions he faces if ignored the provisions concerned, and other matters related to the possession and use of land that he has.

Summarizing Lawrence M's theory. Friedman that in the legal system there are always 3 components, each: 
- The structure, namely the entire existing legal institutions as well as their officers, includes, among others, the police with their, prosecutors with their prosecutors, courts with their judges, and others.

- Substance, i.e., the entire rule of law, legal norms and legal rules, both written and unwritten, including court decisions.

- Legal culture, namely opinions, beliefs (beliefs), habits, ways of thinking and how to act, both from law enforcement and from citizens about the law and various phenomena related to the law.

Achmad Ali added two elements of the legal system, namely;

- Professionalismis an element of ability and skill in person from figures of law enforcement, and

- Leadership is also an element of ability and skill in person from law enforcement figures mainly among law enforcement officials. (Achmad Ali, 1996: 32)

The legal system put forward by Lawrence M. Friedman is very popular among experts even by practitioners, including introducing into the framework of the existence of land services based on Government Regulation No. 10 of 1961 which was later replaced with Government Regulation No. 24 of 1997 on Land Registration. Based on the description above, it is considered important to be studied more deeply.

\section{Method of Research}

This study uses empirical legal research methods, especially factors that affect the implementation of land registration in the perspective of preventing the occurrence of state administrative disputes. While this type of research is descriptive research that describes the findings of data obtained as the results of research and describes it clearly and precisely following the provisions of the legislation that has relevant relationships.

\section{Research Result and Discussion} disputes

The Nature of Land Ownership Registration in Perspective prevention of the occurrence of state administrative

Land registration activities to realize the legal certainty of land rights, then there are two things need to get inventory, research and legal studies, namely: Collection and Processing of Physical Data, including:

- Creation of a basic map of Land registration; consists of the installation of basic point measurement techniques, the creation of a basic map, maintenance of the basic framework points of national engineering.

- Determination of land boundary areas consists of preparation/creation of boundary markings of land boundary determination (land boundary approval), as well as maintenance of land boundary marks.

- Measurement and mapping of land areas and creation of registration maps.

- Proof of Rights and Their Bookkeeping, including:

- Proof of new rights (Article 23 of Government Regulation No. 24 of 1997) consists of the right to a new land, management rights, waqf land, property rights of flat units, dependent rights.

- Proof of old rights consists of proof/origin of conversion (Article 24 paragraph 1 Government Regulation No. 24 of 1997) and no more proof of mail (Article 24 paragraph 2 Government Regulation No. 24 of 1997).

- Bookkeeping rights (Article 30 Government Regulation Number 24 of 1997).

To realize the legal certainty of land rights, the officials/ranks of National Land Agency as the person in charge of registering and bookkeeping the rights to the land must conduct a careful and thorough assessment and research on the land area to be granted the status of rights to the land, so that it materializes the legal certainty of land rights and protection of the rights of land rights holders.

The fact of the relationship between man and the land can be seen as a legal fact, namely, facts or facts that are regulated and given consequences by law, so it can also be called rechtsfeiten. Rechtsfeiten here is defined by legal events, i.e. events that occur in a society that is regulated and given consequences by law.( Utrecht E., 1966: 244)

Researchers agree with Utrecht that the land as the surface of the earth is inhabited by humans, giving birth to legal interactions with the land is both used as a place to live, office, cultivate, try/business and so on. This relationship will give birth to civil rights on the land that is the legal relationship between the person and the land. This is the role of the National Land Agency officials to conduct a systematic, transparent, accountable, objective assessment in the framework of the collection and processing of physical data as well as the proof and bookkeeping of land rights supported by an adequate land service legal system, namely the legal substance, legal structure, public legal awareness, facilities and infrastructure, coordination, and support of land rights that must be mutually integrated into the process of granting land rights that are legally correctly reviewed from the certainty of aspects of land rights, certainty of land rights, and certainty of land rights.

With the pattern and system of land, registration implementation will realize the order of land law and the order of land administration so that a certificate of land rights can be born, especially the certificate of property rights on land as a beschikking product that can be accounted for both from the aspect of an administrative order in the theoretical perspective, administrative order in conceptual perspective, an administrative order in the perspective of state administrative law, so that it can be prevented from disputes of state administration and provide legal protection and legal protection of land rights for owners. 


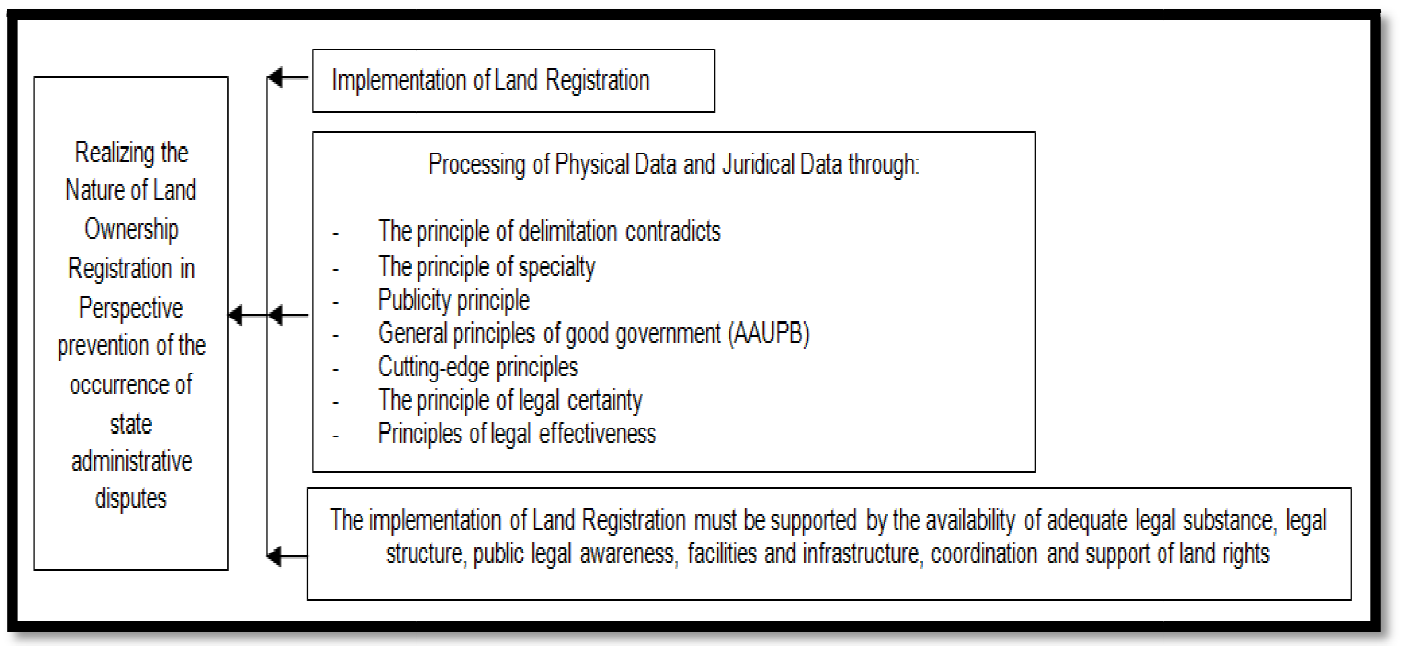

Figure 1: Scheme to Realize Legal Certainty of Land Rights Registration

Based on the scheme, it is clear that in order to realize the nature of the registration of property rights on land in the perspective of preventing the occurrence of state administrative disputes, the land registration system in Indonesia that adheres to the negative system must be changed to a positive system by conducting an in-depth assessment of the processing of physical data and juridical data that is transparent, accountable, objective, up-to-date in the registration of land rights through the consistency of the implementation of the principle of contradiction , the principle of specialty, the principle of publicity, the General Principles of good governance (AAUPB), the principle of cutting-edge, the principle of legal certainty, the principle of legal effectiveness and the implementation of land registration must be supported by the availability of adequate legal substance, legal structure, awareness of community law, facilities and infrastructure, coordination and support of land rights.

In the implementation of land, registration can run efficiently and effectively to realize the legal certainty of land rights must be supported by a system device that adequate and synergy with each other form a legal system of land services that include the availability of adequate legal substance, legal structure, legal culture, public legal awareness, facilities and infrastructure, coordination and support of land rights.

Based on the legal facts above according to researchers must be immediately corrected factors that have a significant effect in the framework of the implementation of land registration to realize legal certainty of land registration, especially property rights on land, if not immediately corrected regularly, measurably and systematically and continuously, it will enlarge the occurrence of land disputes.

The substance of the law stipulated in Government Regulation No. 24 of 1997 relating to the processing of data on the evidentiary rights and bookkeeping stipulated in Article 24 paragraph 2 does not explicitly formulate a concrete explanation of the article, thus providing an opportunity for interpretation of the ranks of the National Land Agency varies, therefore this Article needs to be more concrete and there must be a special assessment that applies generally and uniformly among National Land Agency in providing land services in the proof and bookkeeping of land rights that the owner of the document the right to land in writing does not exist at all only based on physical mastery for approximately 20 years.

This gives room for land disputes because many land cases that occur in fact, he who controls the land continuously even for decades he worked on the land but not as the owner, if this happens will cause land law problems that lead to the emergence of state administrative disputes in the state administrative court. This process often occurs in the activities of publishing land rights in land projects such as Agrarian National Operations Project, Adjudication, and so on.

Concerning the legal structure of land services also according to researchers based on the results of the study showed that to realize legal certainty in the land service legal structure plays a very urgent role, especially related to the quality and quantity of human resources of the ranks of the National Land Agency, human resources National Land Agency apparatus is strongly felt to be the efforts to foster and improve quality and quality through the level of education Bachelor, Magister doctorate as well as special coaching of technical personnel measurement, mapping and technical personnel determination of rights in the processing of juridical data in the process of registration of land rights.

Moreover, this decade the National Land Agency is required in expanding the mandate and responsibility of accelerating land registration throughout Indonesia. To realize the legal certainty of land rights, it is necessary to recruitment employees of the National Land Agency quality, professional let alone the government program efforts to accelerate the registration of property rights to land through the program National Agrarian Operation Project, Adjudication, and so forth where the reality of technical and juridical personnel is strongly felt in the alignment of the National Land Agency both in terms of quality and in terms of inadequate quantity.

Providing land services in the implementation of land registration required the availability of legal substance (land law devices) and legal structures (Human Resources Officials of the National Land Agency both in terms of quality and quantity of proportional and professional) adequate to realize excellent services with legal certainty in the registration of land rights, wherein all land offices district/city in South Sulawesi is strongly felt the lack of personnel/employees of the National Land Agency and need to be further held technical development and land 
administration in stages and continues to provide quality of objective and proportional land services.

According to the researchers turned out at the Makassar City Land Office, Parepare Land Office, Palopo City Land Office, Bulukumba District Land Office which if presented the number of measurers/measuring personnel each district/city has only about 4 people who are faced to do measurement work, mapping to produce a measuring letter on a field of land both routine service work and land projects. It is very irrational and disproportionate to carry out work with their numbers very less, let alone faced with land project activities such as prone, Adjudication, and so on the number at each Land Office reaches approximately 1,000 areas of land rights certificate that must be issued annually at the Land Office in South Sulawesi Province therefore, it is appropriate and necessary to immediately improve the quality and quality of Human Resources National Land Agency, through employee recruitment let alone now there are many interns/honor workers in each Land Office city/district that has a background in land education that has been registered and recorded on the proposal of the appointment of Employees of the National Land Agency of the Republic of Indonesia both the status of contract personnel 1 and contract personnel 2 in the scope of the Regional Office of the National Land Agency of South Sulawesi Province, should immediately they were appointed as employees of the National Land Agency to support land tasks that today are felt the increasing intensity and require intensive and accountable handling.

Legal culture is one of the things that need to get special emphasis and done in providing land services. According to researchers, legal culture is very related to the work environment wherever we devote ourselves, such as among others in the work environment of the National Land Agency, if the work environment gives the influence of intensive legal culture, it will realize the existence of a dynamic work ethic in the application of law consistently and sustainably to organize a fair, honest and objective land service.

This legal culture can only be applied in parallel with the National Land Agency/Land Office if there is a conscientiousness that is knotted on the accuracy of intellectual ability, the accuracy of spiritual/moral abilities, and the accuracy of emotional abilities. Based on the above description if it can synergize the elements, then the land service can be realized effectively and efficiently that has legal certainty. The establishment of legal culture in the alignment of the National Land Agency/Land Office will have a significant influence on the establishment of public legal awareness of land law devices, to coordinate supported by adequate facilities and infrastructure, the processing of physical and juridical data concerning the support of land rights, especially property rights to land (certificate of property rights to land) can realize certainty and legal protection or protection to land rights holders.

The active role of the land registration officer will maintain the right of the person later so that once the land is registered in his name, the legal guarantee of the name in the certificate is no longer possible to deny its validity. That what is stated by Muhammad Yamin, researchers strongly agree that by adopting or adhering to the land registration system with a positive publication system, then the guarantee is more certain, because this positive system provides a guarantee of legal certainty of the right to the land to a person, from the beginning should be thoroughly examined the history of the land (according to the scheme of researchers pictured above.

Land registration is a series of activities carried out by the government, namely the Land Office conducted continuously, continuously and regularly, including the collection, processing, bookkeeping, and presentation and maintenance of physical data and juridical data, in the form of maps and lists, on land areas and units of flats, including the provision of proof of rights to areas of land that already have rights and property rights to units of flats and certain rights that burden them.(Syahruddin Nawi,2015: 3)

Land registration procedural is very important, this is because this factor is a supporter of the implementation of sustainable development, and the development carried out is a conscious effort made by the community to achieve a better life. (Auliah Ambarwati, Muhammad Akbar Fhad Syahril, 2021: 5)

The registration of this part of the land will not only manifest the security guarantee of its own in the direction of legal certainty. Even an owner will get perfection from his rights, because of the following:

- $\quad$ There is a sense of security in having the right to land (security);

- Understand very well what and how to expect from the registration (simplicity);

- Guarantee of thoroughness in the system (accuracy);

- $\quad$ Easy to implement (expedition);

- With the cost that can be reached by everyone who wants to register land (cheapness), and

- The future reach can be realized especially on the price of the land later (suitable).

Records of the land registration will be maintained at the land office. Similarly, information about the physicality of the land will be maintained in the form of a land book, so that once the certificate of land rights (proof of rights) is given to those entitled to land, then all activities of the land for the benefit of the owner are completely guaranteed by law. Even if there is a mutation, his rights will be recorded in the land book, and this recording is preserved for the sake of the land for the position of the rightful from it. As long as the content or nature of it can be used or mutated, then no one disrespects if the right to use and right of disposal is granted by the type of rights itself. The reality of the realization of legal certainty applied is the main issue of the law to be concreted.

In essence land registration in addition to functioning to protect the owner also serves to know the status of the land area who owns it, what the rights are, how widespread, for what is used and so on.( AP. Parlindungan, 1994: 13)

The existence of land function is very important and prioritized because it has its meaning both narrowly and widely because the land is a capital for the life of a family, people also feel safe to live (houses, business buildings), planting places, and as wealth. Families who own large and narrow land both in the form of dry land and wetland must have a valid proof of ownership of the land because having a sign of ownership of the land value can increase.

Land problems from the past until now are frequent problem and the settlement sometimes ends in disputes. Both directly related to the court and limited to the family itself which is only caused by problems with the status of ownership 
rights. This is the impact of development that requires a portion of the land of the citizens and an increasing number of residents who are not balanced with the area of land. To ensure the legal certainty of land rights, the government conducts land registration activities. In this activity, landowners can participate in registering their land to be recorded in the land office so that they can be known the boundaries of the land area and the area of land.

Based on Law No. 5 of 1960 concerning The Basic Rules of Agrarian Principles in article 19 paragraph (1) Mentioning To ensure legal certainty by the government-held land registration in all regions of the Republic of Indonesia according to the provisions stipulated by government regulations. (Boedi Harsono, 1999: 541)

Government Regulation No. 24 of 1997 concerning Land Registration and Regulation of the Head of National Land Agency No. 3 of 1997 concerning The Implementation Provisions of Government Regulation No. 24 of 1997. The land registration activities include:

- $\quad$ Soil measurement, mapping and bookkeeping;

- Registration of land rights and transfer of rights;

- The provision of proof of rights that applies as a strong proof tool in the implementation of land registration stipulated in Government Regulation No. 24 of 1997 in principle through two ways, namely:

Sporadic measurement of land fields is the process of tying the location of the boundary of one or more areas of land based on the application of the rights holder or prospective new rights holders who are located bordering or scattered in one village/village in the framework of sporadic land registration.

Systematic measurement of land fields is the process of systematically trying the boundaries of fields located in one or more villages/villages or several villages/villages or more to systematically implement land registration.

The implementation of land area measurement activities is carried out by employees of the National Land Agency who are given special authority as a measure by licensed surveyors, both cadastral surveyors and cadastral surveyors assistants.

This is intended for the implementation of mapping and measuring activities following the procedures, mechanisms, and technical specifications that have been standardized in Government Regulation No. 24 of 1997 concerning Land Registration and Regulation of the Minister of Agrarian State/Head of National Land Agency No. 3 of 1997 concerning The Implementation Provisions of Government Regulation No. 24 of 1997 concerning Land Registration. Measurement of land fields is carried out to determine the geographical location, area of the land area, determine geometric shapes as attachments in the certification of land rights.

Measurement of land field is the process of proofing the location of one or more land areas based on the application of the rights holder or prospective new rights holder who is located bordering or scattered in one village/village in the framework of land registration (Regulation of the Minister of Agrarian State/Head of National Land Agency No. 3 of 1997). Soil field measurement is carried out to determine the geographical location, geometric shape, area, land field situation for certificate attachment, registration map creation and specially to obtain data on the size of the land field as an element of boundary return, if because of something the boundaries of the land field is lost. The measurement data of each area of the soil must be tied to the existing tie point. A tie point is a point that has coordinates obtained from measurement and calculation in a particular system that serves as a control point or tie point for measurement and reconstruction of boundaries (Regulation of the Milking No. 24 of 1997).

If there is no technical base point around the ground, the measurement can be tied to details that are easily identified in the field such as the corner of the wall, electricity poles, crossroads offences, and so on. The final product of the measurement of land areas is land registration maps made village by village in their entirety and equipped with a list of subjects for their rights. Land registration maps are the result of sporadic measurements containing all areas of land in a village accompanied by data on land rights subjects. Following the legal principle of land, the registration map has had the strength of evidence, because the boundaries of the field have been set and measured by paying attention to the principle of delimitation contradict. Thus, it will legally facilitate the return of the border signs if at any time needed. Map of land registration before it is determined both the subject and the object of rights (the subject) in fulfilling the principle of publicity and the announcement of the object of rights that includes the location, boundaries, and extent in fulfilling the principle of specialty.

Following Article 19 paragraph (2) of the Agrarian Basic Law, there are land registration tasks that are administrative and technical. Administrative duties concerning land bookkeeping, registration of land rights, registration of transfer and provision of proof of rights. While the technical task consists of measurement and mapping. According to the provisions in Article 2 of Government Regulation No. 24 of 1997 related to administrative aspects are mentioned as juridical data, while technical aspects are mentioned as physical data.

Juridical data means information about the legal status of the listed land, rights holders and rights of other parties and other burdens that burden it. If it is declared as the legal status of the registered land field, there is evidence that indicates a legal relationship between the person and his land. The existence of evidence of legal relationship is then formalized (not legalized) through land registration activities. Affirmed formalization is not legalizing because the land registration activities carried out by the agency of the National Land Agency has not been in the position of granting material truth assurance of the ownership of a person's land, but only to the justification or confirmation of formal evidence submitted by the party applying for the right to written evidence issued by the official given authority for it submitted by the applicant as evidence of the possession or basis of rights or legal relations between the person concerned with his land.

The testing of the material truth of any written evidence submitted by the applicant of land rights has not currently been taken over by the National Land Agency of the Republic of Indonesia in the framework of the implementation of land registration, but it remains the authority of the judiciary to examine, examine and test the material truth. This is reinforced by the argument that land registration according to government regulation system No. 24 of 1997 
still uses a negative publishing system.

Land registration activities that formalize land ownership both based on evidence of ownership and control of land in addition to the juridical and technical aspects, as well as the implementation of land registration related to administrative tasks. In other words, inland registration activities there are administrative tasks, such as in terms of land rights determination and land rights transfer registration. It can even be said that activities related to juridical aspects of the collection of juridical data to the publication of land books, certificates and other public lists as well as the recording of changes in the future are almost entirely related to administrative tasks.

The administration process of land registration activities, concretely marked by the existence of lists of fields given certain codes to record each activity of land registration. The list of fields in a list provided at the Land Office in the framework of land registration business administration activities, the list of which is provided in a separate book. The list of fields is stipulated in Article 140 of the Regulation of the Minister of Agrarian State/Head of the National Land Agency Number 3 of 1997. Administrative activities in land registration after the land is registered in Article 36 of Government Regulation No. 24 of 1997 is also called the maintenance of land registration data. The activities can be divided into three categories, namely;

- Activities before the issuance of land certificates (determination of land rights).

- Activities after certificate issuance (change of juridical data).

- Activities after certificate issuance (physical data changes).

In this case, it can be explained that activities that are administrative before the issuance of land certificates in the form of land rights determination include:

- Land Rights Conversion;

- Recognition and Affirmation of Land Rights;

- Granting Of Land Rights;

- Denial of Land Rights;

- Land Redistribution and Land Consolidation;

- Land Clairvoyance.

The process of administrative activities after the issuance of land certificates conducted due to changes in juridical data (subject of rights, types of rights and periods of rights to the land), consists of:

- Transfer of Land Rights;

- Transfer of Land Rights;

- $\quad$ Extension of Term of Land Rights;

- Land Rights Renewal;

- Change of Land Rights;

- Cancellation of Land Rights;

- Revocation of Land Rights;

- Imposition of Land Rights;

- Data Changes Due to Court Rulings and Determinations;

- Data Changes due to Name Changes;

- Removal of Land Rights, and

- Replacement of Certificates.

While administrative activities after the issuance of land certificates carried out due to changes in physical data or objects of land rights, consists of;

- Soil Division;

- $\quad$ Separation of Land Fields;

- $\quad$ Merging Land Fields.

Land administration studies are included in the field of public administration. State administration as a whole activity carried out by all government apparatus of a country to achieve the state goals. Similarly, the activity of realizing the orderly administration of property registration of land in a theoretical perspective is a series of administrative activities, namely administration of land services. Therefore, with the issuance of regulation Government Regulations No. 24 of 1997 instead of Government Regulation No. 10 of 1961 there has been a change in the implementation of land registration in Indonesia. Provisions of Article 19 of Law No. 5 of 1960 concerning The Regulation of Agrarian Principles, because it is described in more detail, as follows:

- With the issuance of a certificate of land rights, the owner is given legal certainty and legal protection;

- With the land information available in the land office, the government will easily plan the development of the country that concerns the land, even for the people themselves are better aware of the conditions of land allocation and ownership;

- With good land administration will be maintained the future of planned land.

\section{Conclusion}

The nature of the registration of property rights on land in the perspective of preventing the occurrence of state administrative disputes is to realize legal certainty through the management of physical data and proof of rights in the registration of property rights on land and implement concrete and accountable certainty of administration and presentation of information, especially the registration of property rights on land has not been running effectively. 


\section{References}

i. Achmad Ali. Menguak Tabir Hukum, Cetakan I. Chandra Pratama. 1996.

ii. AP. Parlindungan, 1994, Bunga Rampai, Hukum Agraria serta Landreform, Bagian III, Mandar Maju, Bandung.

iii. Auliah Ambarwati, Muhammad Akbar Fhad Syahril, 2021, Pendaftaran Tanah Sistematis Lengkap, Efektifkah, Jurnal Dinamika Hukum, Vol 22 (1), p. 5.

iv. Lutfi I Nasution, 2002, Menuju Keadilan Agraria 70 tahun, Akatiga, Bandung.

v. Syahruddin Nawi, S. (2015). Kapita Selekta Hukum Pertanahan. CV. Fharras Jaya Grafika.

vi. Utrecht, 1966, Pengantar Hukum Indonesia, Cetakan IX, PT. Penerbitan Universitas, Jakarta.

vii. Kitab Undang-undang Hukum Perdata

viii. Undang-undang Nomor 5 Tahun 1960 Tentang Peraturan Dasar Pokok-Pokok Agraria

ix. Peraturan Pemerintah Nomor 10 Tahun 1961 tentang Pendaftaran Tanah, yang kemudian disempurnakan dengan Peraturan Pemerintah No 24 tahun 1997 tentang Pendaftaran Tanah

x. Peraturan Menteri Dalam Negeri Nomor 2 Tahun 1978 tentang Biaya Pendaftaran Tanah

xi. Peraturan Menteri Agraria Dan Tata Ruang/Kepala Badan Pertanahan Nasional Republik Indonesia Nomor 28 Tahun 2016 Tentang Percepatan Program Nasion l Agraria Melalui Pendaftaran Tanah Sistematis. 